\title{
Are Knowledge-Intensive Services an Urban Growth Factor in the Global Periphery? (Un)Fulfilled Possibilities in the Large Metropolitan Areas of Mexico
}

\author{
Boris Graizbord ${ }^{1}$ and Luis Enrique Santiago ${ }^{2, *(D)}$ \\ 1 Center for Demographic, Urban and Environmental Studies, El Colegio de México, Mexico City 14110, \\ Mexico; graizbord@colmex.mx \\ 2 Department of Urbanism and Urban Planning, Universidad Autónoma de Aguascalientes, Aguascalientes \\ 20131, Mexico \\ * Correspondence: luis.santiago@edu.uaa.mx; Tel.: +52-449-910-74-00 (ext. 54401)
}

Received: 17 October 2020; Accepted: 2 November 2020; Published: 4 November 2020

\begin{abstract}
In this paper, we analyze the labor productivity of "knowledge-intensive services" (KIS) located in the four larger metropolitan areas in Mexico. We discuss the accepted explanation to why big cities concentrate the best and most qualified jobs and activities that generate innovative and technological change and therefore labor productivity. In Mexico this is the case for some knowledge-intensive sectors, but some paradoxes emerge when services are disaggregated by analytical, synthetic, and symbolic categories. We use disaggregated economic census data for 2004 and 2014 to find changes in labor productivity in those KIS sectors compared to the metropolitan service economy. In fact, we can identify different spatial logic according to the type of knowledge that KIS produce. Results show unexpected paradoxes in terms of type of KIS category viz a viz their location and growth performance in the four larger metropolitan areas.
\end{abstract}

Keywords: knowledge intensive service sectors; economic growth; metropolitan areas

\section{Introduction}

Knowledge-intensive services (KIS) are a key factor in the global economy due to their function in innovative processes [1], their capacity in adopting and embodying technological change [2], in employing qualified workers [3], reaching high productivity, and generating growth and wealth [4]. KIS include industries focusing on science, engineering, biotechnology, as well as financial, legal health services, and also art and culture as well as highly sophisticated leisure activities [5,6].

Evidence shows these types of activities tend to locate in the larger national urban centers [7-9]. Two arguments are advanced to explain this tendency: first, human capital is usually located in those large cities and, second, the dense urban context provides learning conditions and exchange of knowledge opportunities. Camagni's [10] spatial innovative milieu concept provides the rationale to understand the cultural meaning of agglomeration economies generated by large metropolitan areas and how these are taken advantage of by specialized occupations finding opportunities to interact and exchange knowledge in a spatial proximity that assures face-to-face contact. These attributes do accelerate the rate of exchange of knowledge (codified and informed or tacit), technological innovation, productivity growth, and value generation, at least in developed countries [11,12].

Our approach is based on Piore and Sabel [13], who in the early nineteen-eighties acknowledged that the "second industrial divide" was transforming the economic performance of industry and thus changing the traditional economic structure that Fisher [14] and Clark [15] at the time divided into 
primary, secondary, and tertiary sectors. The main problem in still using this traditional division to describe the structure of the economy, as was indicated, among others, by Piketty [16] (p. 108, note 17), is the fact that services dominate in most cases. He notes that: "[ .. ] services require between $70-80 \%$ of the work force in both developed and developing countries ... based on his fact, the conventional sectors are not pertinent and provide little information on the trades and services provided ..." . Therefore, we classify data heuristically as follows: no matter the economic activities, there are those that use knowledge intensively and those that do not need to do so and are carried out rather routinely by non-qualified workers [17] (p. 335). It is therefore possible to classify economic activities dividing knowledge-intensive activities performed by creative workers from those carried out routinely by a labor force poorly educated and with low qualifications. The question is, can these processes also be recognized in large urban centers in the Global South? A relevant question, since studies on those numerous large metropolitan areas in developing countries are relatively few (directly on the subject: [18,19]; related to the topic: [20-22]).

To describe the interrelated effects of agglomeration economies in these activities, we measure the pattern of concentration of services according to intensity and type of knowledge and its relationship with labor productivity in the four larger metropolitan areas in Mexico: Mexico City Metropolitan Area (MCMA), Guadalajara Metropolitan Area (GMA), Monterrey Metropolitan Area (MMA), and Puebla-Tlaxcala Metropolitan Area (PMA). Our central hypothesis argues that despite the marginal position of our cities in the world urban system [23], knowledge-intensive services (KIS), as they occur in developed countries, are mainly concentrated and reach the highest productivity levels in the larger metropolitan areas. The results partially corroborate our hypothesis. Although KIS present levels of productivity and wages above the national average in the four larger metropolitan areas, these levels have decreased to levels close to those of 'non-knowledge-intensive' activities. These results represent a "paradox" [24,25] on the idea of considering KIS as possible "engines" of economic growth in large cities on the global periphery, as they represent evidence contrary to that expected by the literature. We divide the text in four sections in addition to this introduction. In the second section, we point to changes in the structure of the economy emphasizing the importance of KIS, and their effects on wage levels and labor productivity, highlighting the relationship between KIS and large cities. In the third section, we specify the sources of information and data used in our analysis; next, we discuss findings and finally we present some conclusions.

\section{Knowledge, Economic Transformation, and the Urban Milieu}

Developed countries have experienced an economic transformation resulting in a decline in manufacturing employment (blue collar/middle income) and growth in service employment (white collar/high income). This transforming process has produced a sound division or polarization in the urban labor market. On the one hand, jobs requiring high content of skills (high skills), knowledge, and creativity; on the other, a large diversity of jobs that require low or no special skills or knowledge [26-28]. The first, defined in this paper as KIS, includes jobs with high salaries, highly productive [29], even larger than those in capital-intensive activities in agriculture and manufacturing [30,31]. Results are based on the role these activities play as "innovators" [32] or as "bridges" [33] in technological innovation processes, scientific discoveries, and artistic-cultural creations [1]. The second represent a broad group of "non-knowledge-intensive service" (NKIS) jobs with low salaries and poor productivity levels [34].

This polarizing process between both groups of services is attributed to (i) technological change (fourth industrial revolution) [35]; (ii) globalization [36]; and (iii) increased need of employment standards in production and consumption services (not necessarily excluding each other) [37]. The result is reflected in a demand for jobs based on knowledge and (specialized) high-skills jobs accompanied by a strong demand of low salaries jobs producing an increasing gap between both types of service employment $[38,39]$. 
To identify the changes indicated previously some authors have proposed an alternative classification that distinguish intensity and type of knowledge involved in any activity $[2,16,40,41]$. However, proposals usually present two limitations. First, they focus on the study of 'Business Services' and do not recognize that workers with high levels of knowledge and skills produce some consumer services. Among those, "[ ... ] design professions like architecture, engineering and planning, fashion and industrial design; creative and cultural industries, ranging from live performing arts though galleries and museums to the print and electronic media; education and research; health services for an ageing and health-conscious population; and both business and leisure tourist services" [42] (p. 811). Second, they offer no information about the function of knowledge-intensive services (KIS) in the generation of scientific discoveries, technological innovations, and artistic creations. Asheim [43] provides an alternative framework by classifying service industries in analytical (scientific knowledge), synthetic (technical knowledge), and symbolic (artistic and cultural knowledge) service categories.

The previous changes have specific spatial dimensions. Manufacturing jobs were lost in larger cities but relocated to other urban centers both nationally and globally [36]. At the same time, a substantial growth of services employment occurred in the larger cities [11]. In this process, KIS have shown outstanding levels of spatial concentration and growth rates in the city that occupies the first position of the urban hierarchy. The big city concentrates the most advanced, innovative, productive, and better-paid jobs, while the same services located in other cities of the urban system do not have the same positive results. The literature is overwhelming in pointing to this relationship between city size and KIS location (some examples are: [12,18,19,44-50]). NKIS, on the other hand, have shown a slower growth rate and a spatial distribution more associated with the demographic weight of the cities that make up the urban systems.

The spatial concentration of KIS and its positive results in large cities have two possible explanations. In the first, the key element is the composition of the labor market of large cities [51]. It assumes a gap in the educational level of workers who live in large cities and those located in other cities of the urban system. That is to say, the most productive and innovative workers prefer big cities; thus, firms located in those cities benefit from higher productivity and offer better wages [52]. The second perspective underline the advantages offered by large urban agglomerations $[18,50,53]$. These advantages are more oriented to the possibility of transmitting ideas and knowledge than tangible goods [54]. Emphasis is placed on the physical environmental conditions offered by large cities that stimulate the exchange of knowledge and expose individuals to learning. According to Storper and Venables [55], in addition to backward and forward linkages, firms benefit from access to markets, while the clustering of workers, and localized interactions, promote technological innovation [56,57].

The key in the previous argument is face-to-face (F2F) contacts. In the big cities, these are facilitated by spatial proximity, and accelerate the rate of exchange of tacit knowledge, technological innovation, and productivity growth $[11,58,59]$. The innovative milieu found in large urban centers with high densities, diversified economic structure, and urban amenities is key to understanding the possibilities of personal contacts which occur on many levels at the same time-verbal, physical, contextual, intentional, and non-intentional —in formal (education institutions) and informal urban places (coffee shops, bars, parks, etc.) [60-62]. In practice, the exchange of knowledge by F2F contact is not linear. Gertler [63] (p. 91) indicates that it "depends on much more than spatial proximity, cultural affinity, or corporate culture. It depends on institutional proximity-that is, the shared norms, conventions, values, expectations, and routines arising from commonly experienced frameworks of institutions." Through those contacts, workers can have positive spillovers and companies get ideas from their workers and their highly trained suppliers [64].

The previous theoretical positions rest on two premises that we discuss here. First, large cities, due only to their size, meet the conditions (economies of agglomeration) that encourage high spatial concentration and outstanding economic development of KIS. However, this idea does not consider the possible differences between economic contexts where KIS can develop; for example, the basic 
difference between developed and developing countries. Second, these conditions have a positive effect on KIS regardless of their productive orientation or the type of knowledge they develop over time [65]. Thus, a few questions:

(i) Do larger Mexican metropolitan areas concentrate the best and most qualified employment of KIS, as in big cities of developed countries like Canada or England?

(ii) Do agglomeration economies have a similar effect over KIS, independently of its type of knowledge?

(iii) And if so, is the positive effect constant over time?

\section{Data and Methodology}

\subsection{The Four Cases}

The Mexican government has officially defined metropolitan areas. A metropolitan area combines an urban agglomeration (the contiguous, built-up area) with settlements not necessarily urban in character, but closely bound to the center by employment. These outlying areas, known as a commuter belt, may extend well beyond the urban center's jurisdiction [66]. The four most populated, with 21, 4.8, 4.7, and 3 million inhabitants in 2015, are respectively: (1) Mexico City Metropolitan Area (MCMA), (2) Guadalajara Metropolitan Area (GMA), (3) Monterrey Metropolitan Area (MMA), and (4) Puebla-Tlaxcala Metropolitan Area (PMA). Different geographic and economic attributes distinguish them. MCMA is the political and still the most important economic center in the country. Fifth in size in the world, it is historically the national metropolis and the country's capital $[67,68]$. GMA is the second in size and the cultural and economic urban center for the country's western territory. MMA is third and the connection to the US markets in financial, industrial, and cultural areas. PMA, a city $240 \mathrm{~km}$ to the east of Mexico City, keeps its traditional character as a cultural and historical center. (Figure 1).

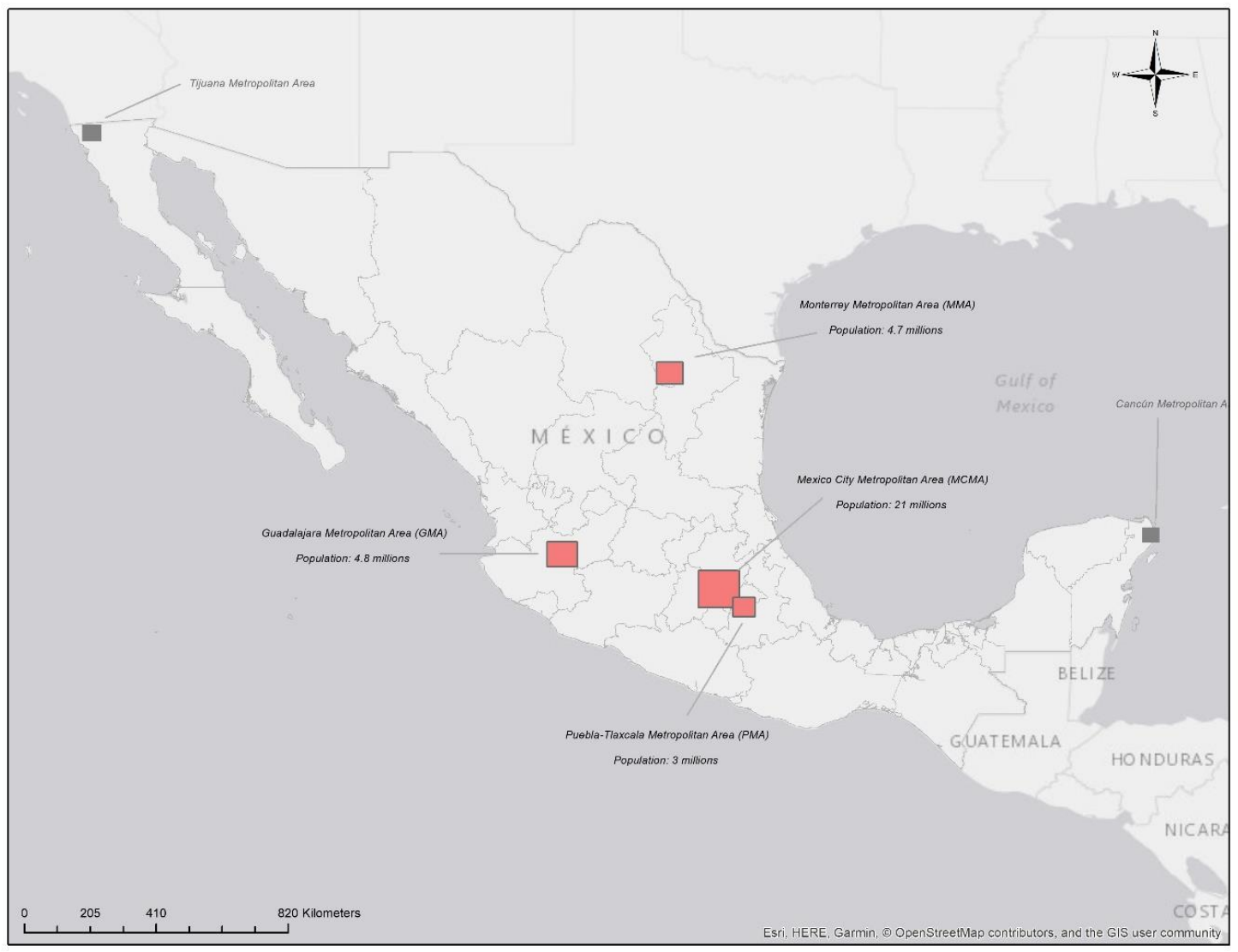

Figure 1. Mexico: Large Metropolitan Areas of Mexico. 
The four metropolitan areas have been subject to government efforts to develop specialized clusters in high tech in order to position them in a global perspective $[69,70]$. Nevertheless, except for MCMA, they are still far away from the global cities (London, New York, Paris, Tokyo) or the Asian emerging metropolis (Shanghai, Beijing) in global rankings (i.e., [71-74]). Only Mexico City appears as a Beta World City next to Sao Paulo, Brazil. Additionally, Tijuana, a Northern border city, is mentioned as with "minimal evidence of world city formation" [23]. However, as peripheral "actors", the four play a functional role in the world economy $[67,75]$.

\subsection{Data and Indicators}

For information on employment, value-added, and paid salaries, we used data from the 2004 and 2014 economic census [76,77]. Based on the standard classification of economic activities (North America Industrial Classification System, NAICS-2007), Santiago [78] identified a very detailed set of disaggregated service sectors in production and consumption (five digits) that use knowledge intensively (Table 1).

Table 1. Definition of knowledge-intensive services (KIS) categories.

\begin{tabular}{ll}
\hline \multicolumn{1}{c}{ Activity by Type of Knowledge } & \multicolumn{1}{c}{ NAIC Classification by Sub-Branch } \\
\hline Analytic knowledge & \\
$\quad$ University education & 61131 \\
$\quad$ Specialized medicine & 62231 \\
$\quad$ Research and development & 54171,54172 \\
Synthetic knowledge & $54133,54136,54151,54169$ \\
High-tech engineering & $54121,54161,55111$ \\
Administration services & $54111,54112,54119$ \\
$\quad$ Legal services & $52111,52221,52222,523111,52391,52399$ \\
Financial services & $61121,61141,61143,61163$ \\
Technical education & $62111,62121,62131,62132,62133,62134,62139,62211,62221$ \\
$\quad$ Non-specialized medicine & $54162,54193,54194,54199,61171$ \\
$\quad$ Diverse services & \\
Symbolic knowledge & $51112,51113,51511,515122,51521,51913,54181,54182,54184,54186,54191$, \\
Massive communication media & $54192,61162,71121,71131,71132,71141$ \\
$\quad$ Cultural activities & $51211,51219,51222,51223,51224,61161,71111,71112,71113,71151,71211$ \\
Design & $54131,54132,54141,54142,54143,54149$ \\
\hline & Source: Santiago [78] (pp. 133-135).
\end{tabular}

We present results on the spatial distribution of KIS categories in these four metropolitan areas. We examined two variables: employed personnel and value-added. The level of concentration of employed personnel was measured by:

$$
\mathrm{p}_{\mathrm{ij}}=\mathrm{n}_{\mathrm{ij}} / \mathrm{N}_{\mathrm{j}},
$$

where $\mathrm{p}_{\mathrm{ij}}=$ percentage of employment of KIS type $\mathrm{i}$ in city $\mathrm{j} ; \mathrm{n}_{\mathrm{ij}}=$ number of people working in KIS type $\mathrm{i}$ in city $\mathrm{j}$; $\mathrm{N}_{\mathrm{j}}=$ total employment in KIS in city $\mathrm{j}$ (depending on the variable, the total of reference could be employment or value-added).

The presence of KIS (or other economic sector) in city $\mathrm{j}$ was measured by the location quotient:

$$
\mathrm{LQ}_{\mathrm{ij}}=\left(\mathrm{e}_{\mathrm{ij}} / \mathrm{e}_{\mathrm{j}}\right) /\left(\mathrm{E}_{\mathrm{i}} / \mathrm{E}\right),
$$

where $\mathrm{LQ}_{\mathrm{ij}}=$ location quotient of KIS (analytic, synthetic, and symbolic) in metropolitan area $\mathrm{j}$; $\mathrm{e}_{\mathrm{ij}}=$ employment of KIS (analytic, synthetic, and symbolic) in metropolitan area $\mathrm{j} ; \mathrm{e}_{\mathrm{j}}=$ total population in metropolitan area $j ; E_{i}=$ employment of KIS (analytic, synthetic, and symbolic) $i$ in the four metropolitan areas; and $\mathrm{E}=$ total population in the four metropolitan areas.

We defined the labor productivity of KIS (2004 and 2014) as a measure of output to a single or a bundle of inputs [79] (pp. 12-13), relating total value added over total employment [48] 
(p. 608). Although clearly the preferred productivity measure would be value-added per hour, Haltiwanger et al. [80] point out that there is a close correspondence both conceptually and in terms of measurement between this measure of gross output at the establishment level and the industry-level measures. The standard measure of labor productivity at the detailed industry level is output per hour [48].

Labor productivity of KIS (and another economic sector) was estimated by:

$$
\mathrm{q}=\mathrm{Q}_{\mathrm{it}} / \mathrm{L}_{\mathrm{it}},
$$

where $\mathrm{q}$ = Labor productivity; Qit = value added of KIS (and other economic sector) in metropolitan area $\mathrm{i}$ at time $\mathrm{t}$; Lit $=$ employment of KIS (and other economic sector) in metropolitan area $\mathrm{i}$ at time $\mathrm{t}$.

To know if better salaries are offered by KIS located in the four larger metropolitan areas, general average salary was used as a benchmark to compare with KIS salaries. We calculated the average salaries through a simple relationship between the total remunerations generated by KIS and their employment in 2004 and 2014 by:

$$
\mathrm{s}=\mathrm{R}_{\mathrm{it}} / \mathrm{L}_{\mathrm{it}},
$$

where $s=$ salary per capita; $R_{i t}=$ total salaries paid to KIS employment (and other economic sector) in metropolitan area $\mathrm{i}$ at time $\mathrm{t}$; $\mathrm{L}_{\mathrm{it}}=$ labor input of KIS (and other economic sector) in metropolitan area $\mathrm{i}$ at time $\mathrm{t}$.

Concentration and specialization in 2014 compared with 2004 show the actual importance and orientation of KIS and its evolution. After presenting some descriptive statistics we examine KIS participation, concentration, and distribution in the four metropolitan areas in 2014 according to the mentioned categories of analytical, synthetic, and symbolic services; then, we proceed to a detailed analysis of labor productivity and salaries of those categories between 2004 and 2014.

\section{Results}

In 2014, of the total 21.5 million formal jobs (personal ocupado) more than seven out of ten were concentrated in services, commerce, and transport activities (38\% in services and $33.2 \%$ in commerce and transport). However, more than nine out of ten of those were NKIS. KIS represented $7 \%$ of the total service employment but their participation in value-added was overwhelmingly above this figure (Table 2).

The four metropolitan areas concentrated around $45 \%$ of employment and $74 \%$ of value-added of total KIS in 2014. The employment decline (3\%) during the period can probably be explained by decentralization of economic activities and population to the rest of the national urban system. However, symbolic KIS increased their metropolitan participation. On the other hand, analytical KIS more than doubled average national growth (Table 2). These data provide an idea of the importance and general characteristics of KIS in Mexico and their propensity to locate in the four larger metropolitan areas in the country. In the following paragraphs we analyze exclusively what happens in these four metropolis.

\subsection{Location}

In general, the levels of relative concentration of KIS employment do not follow the demographic weight of the four national metropolises. Two main KIS nodes in the country were identified: MCMA and MMA. In these two metropolitan areas the levels of relative concentration of KIS employment are higher than the metropolitan average (LQ > 1.00). Both GMA and PMA participation remain below the metropolitan average (Figure 2). Contrary to expectations, the concentration levels of the KIS are only higher than the NKIS in MCMA, while in the other three cases the presence of KIS is relatively lower than the NKIS; especially in MMA. 
Table 2. Mexico and metropolitan areas: concentration of employment and value-added by knowledge categories, 2004 and 2014.

\begin{tabular}{|c|c|c|c|c|c|c|c|c|}
\hline & \multicolumn{4}{|c|}{ Employment } & \multicolumn{4}{|c|}{ Added-Value (Millions of Pesos, $2012=100$ ) } \\
\hline & \multicolumn{2}{|c|}{ Mexico } & \multicolumn{2}{|c|}{4 Metropolis $^{a}$} & \multicolumn{2}{|c|}{ Mexico } & \multicolumn{2}{|c|}{4 Metropolis $^{a}$} \\
\hline & 2004 & 2014 & 2004 & 2014 & 2004 & 2014 & 2004 & 2014 \\
\hline Total & $16,244,843$ & $21,581,179$ & $6,243,357$ & $8,090,774$ & $5,011,371.2$ & $5,801,664.0$ & $2,159,399.1$ & $2,437,375.1$ \\
\hline Services ${ }^{b}$ & $5,231,918$ & $8,214,554$ & $2,133,026$ & $3,372,131$ & $1,503,280.6$ & $1,695,485.0$ & $933,808.2$ & $1,084,251.6$ \\
\hline KIS $^{c}$ & $1,192,134$ & $1,628,575$ & 575,792 & 739,284 & $788,297.5$ & $680,626.2$ & $605,064.4$ & $502,613.9$ \\
\hline Analytical & 153,732 & 282,835 & 60,261 & 105,545 & $34,351.8$ & $44,062.0$ & $17,476.6$ & $19,160.7$ \\
\hline Synthetic & 808,389 & $1,049,029$ & 407,546 & 483,722 & $681,527.8$ & $590,459.5$ & $543,723.6$ & $456,376.9$ \\
\hline Symbolic & 230,013 & 296,711 & 107,985 & 150,017 & $72,417.9$ & $46,104.7$ & $43,864.1$ & $27,076.2$ \\
\hline NKIS $^{d}$ & $4,039,784$ & $6,585,979$ & $1,557,234$ & $2,632,847$ & $714,983.1$ & $1,014,858.8$ & $328,743.8$ & $581,637.7$ \\
\hline Other sectors ${ }^{\mathrm{e}}$ & $11,012,925$ & $13,366,625$ & $4,110,331$ & $4,718,643$ & $3,508,090.7$ & $4,106,178.9$ & $1,225,591.0$ & $1,353,123.5$ \\
\hline \multicolumn{9}{|l|}{ Percentage (\%) } \\
\hline Total & 100.00 & 100.00 & 38.43 & 37.49 & 100.00 & 100.00 & 43.09 & 42.01 \\
\hline Services & 100.00 & 100.00 & 40.77 & 41.05 & 100.00 & 100.00 & 62.12 & 63.95 \\
\hline KIS & 100.00 & 100.00 & 48.30 & 45.39 & 100.00 & 100.00 & 76.76 & 73.85 \\
\hline Analytical & 100.00 & 100.00 & 39.20 & 37.32 & 100.00 & 100.00 & 50.88 & 43.49 \\
\hline Synthetic & 100.00 & 100.00 & 50.41 & 46.11 & 100.00 & 100.00 & 79.78 & 77.29 \\
\hline Symbolic & 100.00 & 100.00 & 46.95 & 50.56 & 100.00 & 100.00 & 60.57 & 58.73 \\
\hline NKIS & 100.00 & 100.00 & 38.55 & 39.98 & 100.00 & 100.00 & 45.98 & 57.31 \\
\hline Other sectors & 100.00 & 100.00 & 37.32 & 35.30 & 100.00 & 100.00 & 34.94 & 32.95 \\
\hline \multicolumn{9}{|c|}{ Change 2004-2014 } \\
\hline Total & & 32.85 & & 29.59 & & 15.77 & & 12.87 \\
\hline Services & & 57.01 & & 58.09 & & 12.79 & & 16.11 \\
\hline KIS & & 36.61 & & 28.39 & & -13.66 & & -16.93 \\
\hline Analytical & & 83.98 & & 75.15 & & 28.27 & & 9.64 \\
\hline Synthetic & & 29.77 & & 18.69 & & -13.36 & & -16.06 \\
\hline Symbolic & & 29.00 & & 38.92 & & -36.34 & & -38.27 \\
\hline NKIS & & 63.03 & & 69.07 & & 41.94 & & 76.93 \\
\hline Other sectors & & 21.37 & & 14.80 & & 17.05 & & 10.41 \\
\hline
\end{tabular}

${ }^{a}$ It is the sum of the four larger metropolitan areas: Mexico City, Guadalajara, Monterrey, and Puebla. ${ }^{b}$ It is the total of services sector and it is the sum of KIS and NKIS. ${ }^{c}$ KIS (analytical, synthetic, and symbolic) from Table 1. ${ }^{d}$ NKIS is formed by the sub-branches (5-digits) that are not defined as KIS of the following sectors: (51) Information in mass media, (52) Financial an insurance services, (53) Real estate, (55) Corporate, (56) Business support services and waste management, (61) Educational services, (62) Health and social assistance services, (71) Cultural, sport entertainment and recreational services, (72) Temporary accommodation and food services, and (81) Other services except government activities. ${ }^{e}$ It is the sum of (11) Agriculture; (21) Mining and extraction; (22) Electricity;

(23) Construction; $(31,32)$ Manufacture; $(43,46,48$, and 49) Trade and transportation. Source: [76,77].

Distribution of KIS in 2014 was like 2004 but some changes were observed. KIS showed negative growth in MCMA and an increase in the other three. The results indicate a tendency to reduce the gap between MCMA and the metropolis that follow in size. An explanation of this trend could be related to the needs of KIS activities to relocate following demand given decentralization processes in the national urban system (Figure 2A). However, although the increase in KIS in GMA and MMA was similar, their economic trajectories were not. The increase of KIS in MMA was accompanied by a significant growth of NKIS, while in GMA the opposite occurred (Figure 2A). This result offers clues to important differences in the production of wealth and wages of KIS between both metropolitan areas, as will be discussed in the following paragraphs.

If we consider KIS categories (analytical, synthetic, and symbolic) we can identify different spatial logics according to the type of knowledge that KIS produce. In 2014, the importance of symbolic KIS was related positively to the size of the metropolitan area. Except MMA, the concentration of analytical KIS was inversely related to the size of the metropolitan area. Synthetic KIS were concentrated in MCMA and MMA, the two traditional economic urban centers of the country. Changes during the period indicate that: (i) analytical and symbolic KIS increased their importance only in MCMA, and (ii) synthetic KIS decentralized from MCMA to the other three metropolitan areas. Previous results suggest two different spatial logics. The first is that analytical and symbolic KIS respond to agglomeration economies; the second, synthetic KIS locate close to clients, with the industrial MMA a clear location (Figure 2B). 
(A)

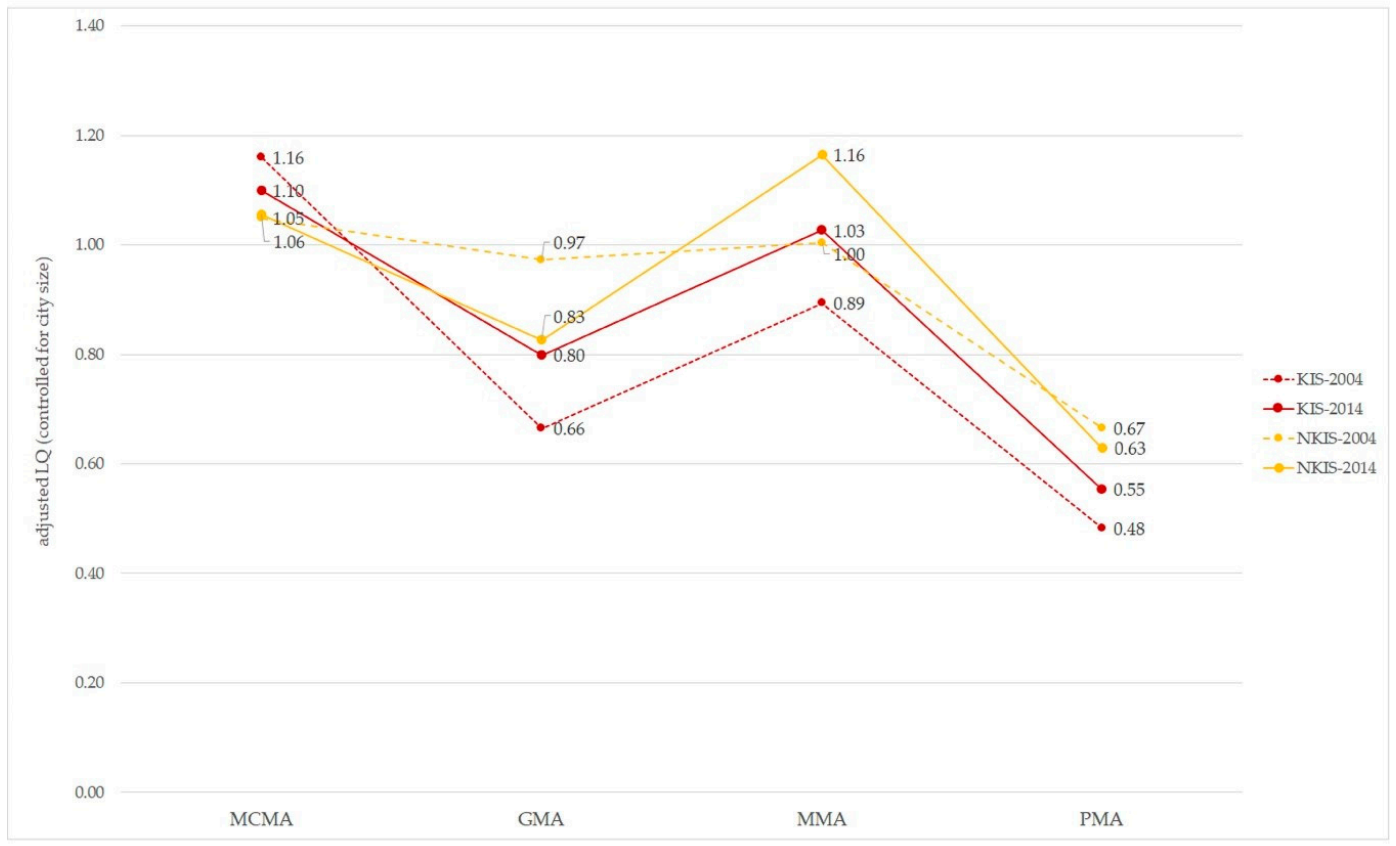

(B)

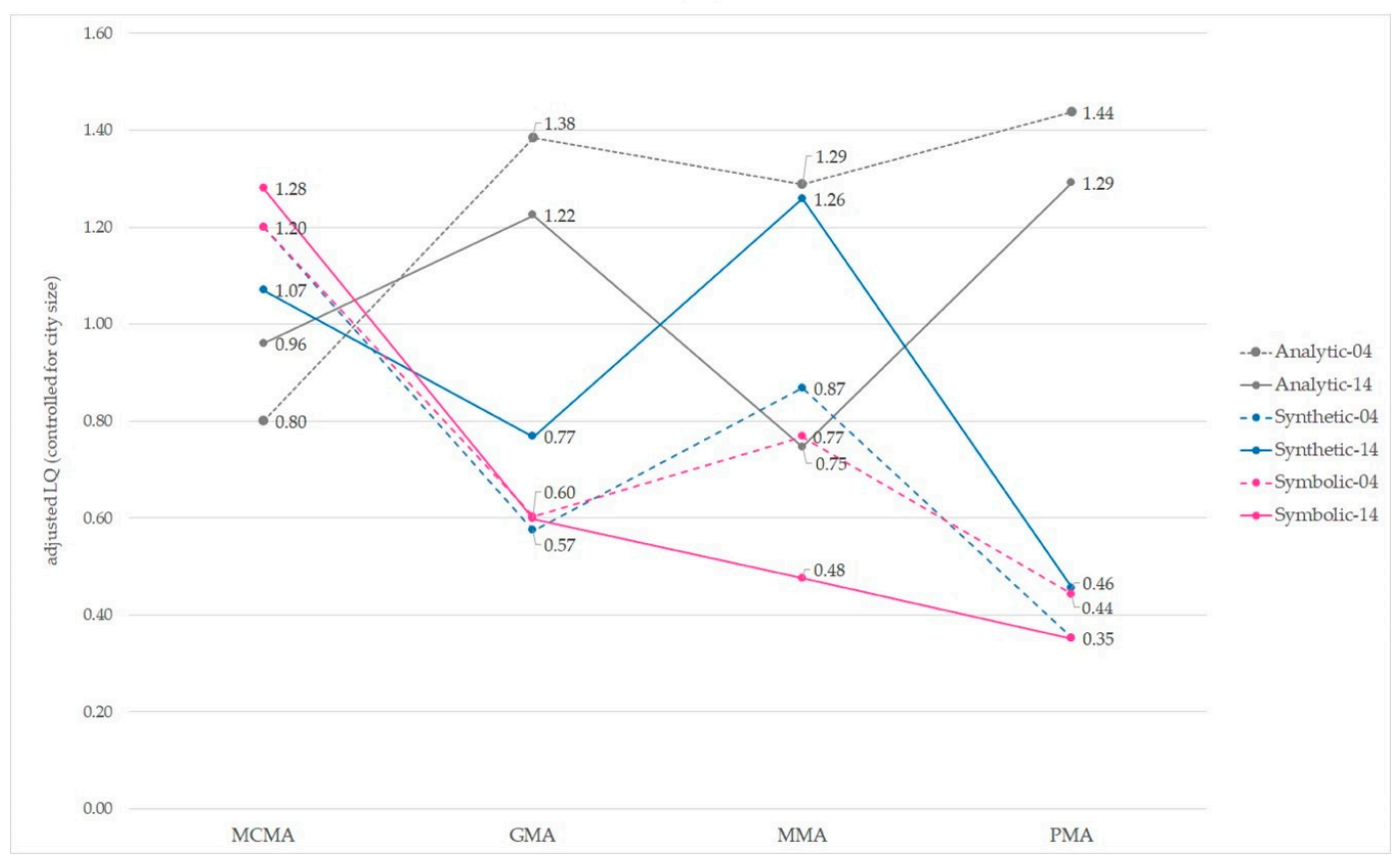

Figure 2. Larger metropolitan areas: KIS and no knowledge-intensive services (NKIS) location quotient, 2004 and 2014. (A) KIS and NKIS location; (B) KIS by type of knowledge location.

\subsection{Productivity}

In México, KIS productivity levels $(q=0.42)$ are above the national median $(0.26)$. Productivity of KIS is only below mining and extraction (6.08) and electricity production (1.13). KIS are just above manufacturing (0.33). However, these last results are different in the four larger metropolitan areas. In general, city size has a positive effect on KIS as far as productivity levels are concerned. Productivity of KIS located in the four larger metropolitan areas (0.68) is almost double (1.6 times) in relation to the country's (see Table A1 in Appendix A). 
Differences among the four metropolitan areas are significant. Levels of productivity are supposed to be associated with size of the urban centers, but in MCMA (0.78) and MMA (0.76) these are much higher. Still, in MCMA the expected level according to size is not met, while it is much larger than expected in MMA according to its size. KIS productivity in GMA (0.18) and PMA (0.11) is significantly lower than the metropolitan average, and even their value is just higher than the NKIS ( 0.09 and 0.08 , respectively) (Figure 3A).

\section{(A)}

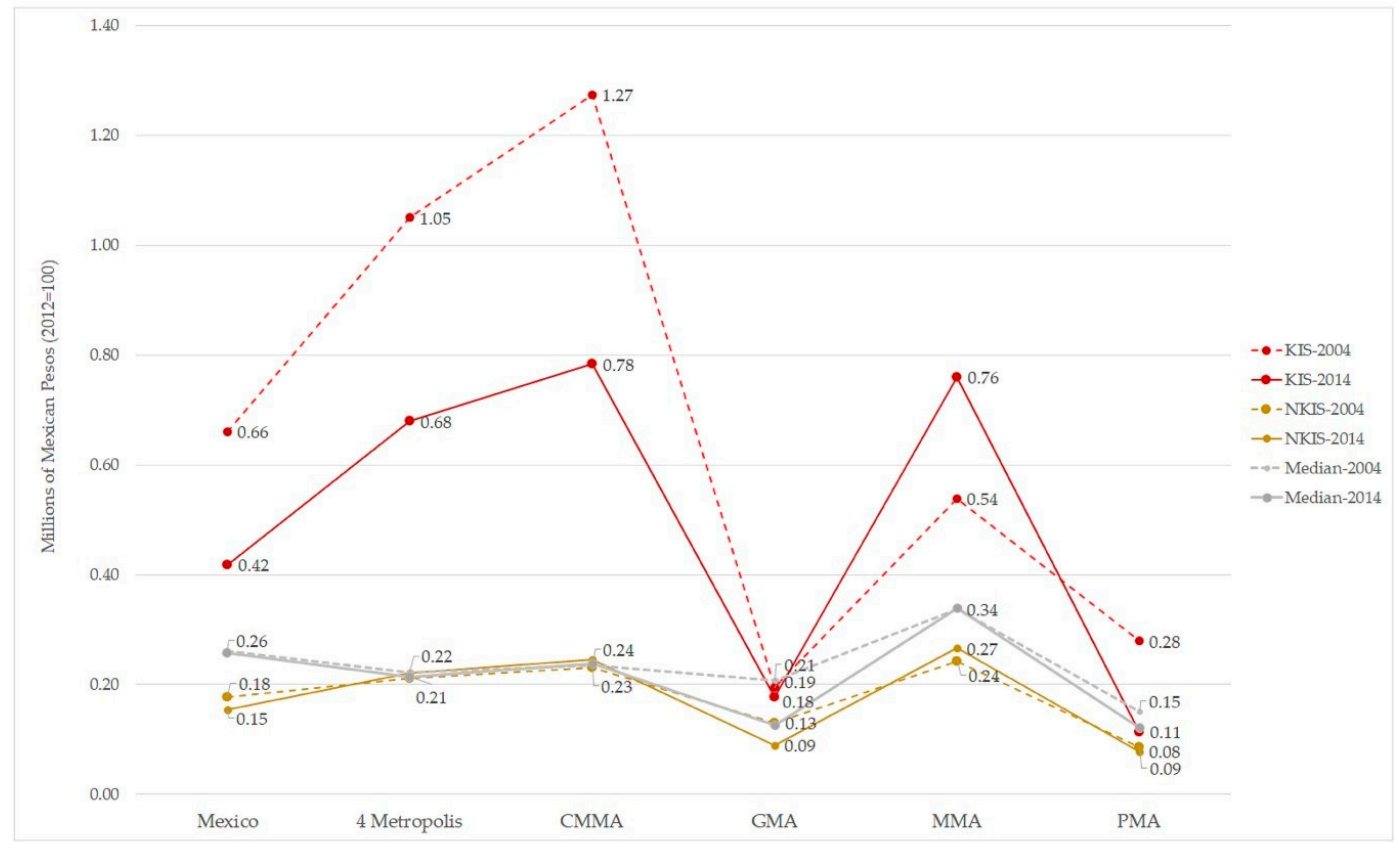

(B)

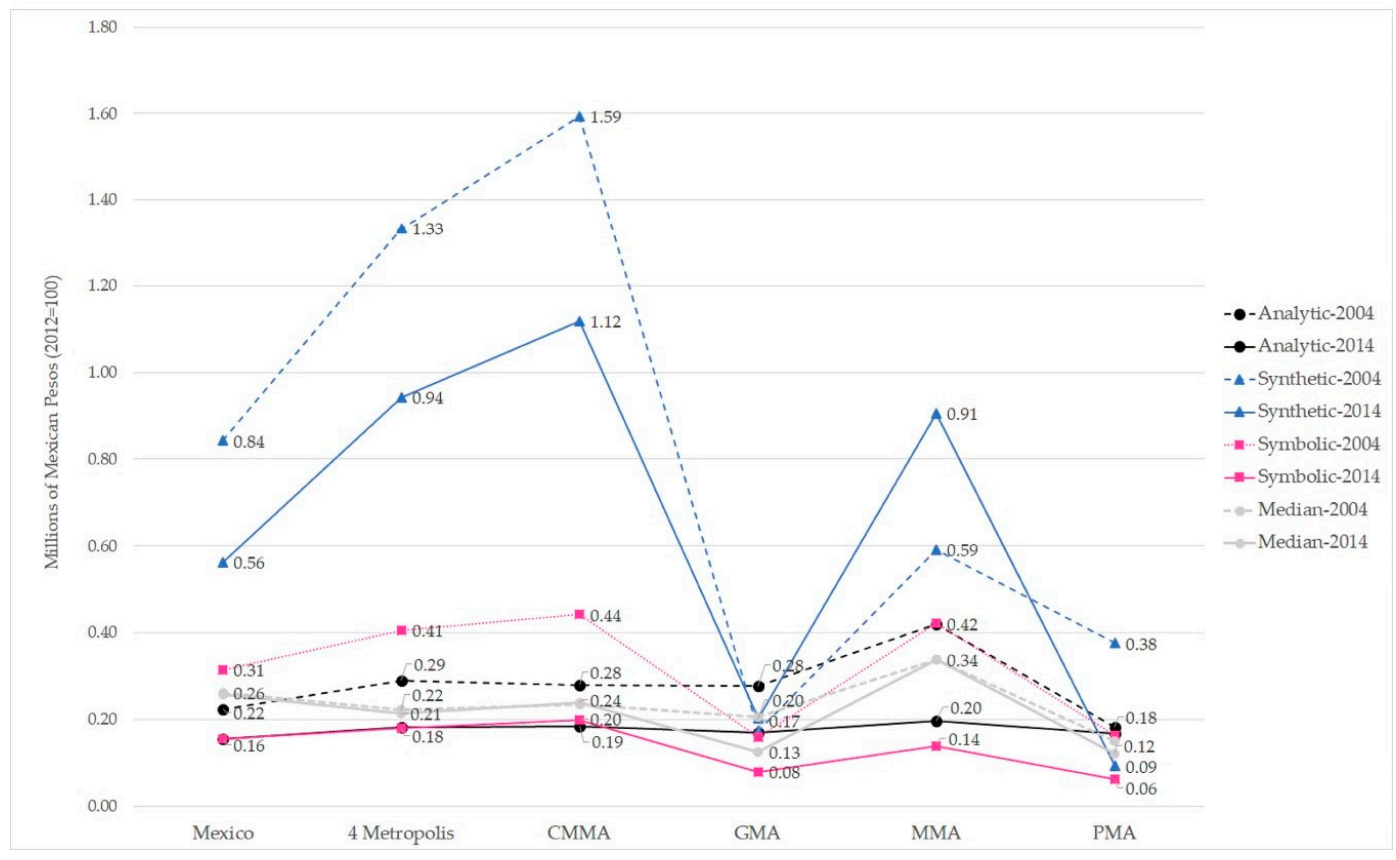

Figure 3. Mexico and four larger metropolitan areas: Productivity of services industries, 2004 and 2014. (A) KIS and NKIS; (B) KIS by type of knowledge. Source: Table A1 in Appendix A. 
The relationship between level of productivity and salaries paid (which are analyzed in the next section) in metropolitan areas according to population size was analyzed using a non-parametric statistic test, chi-square $\left(\mathrm{X}^{2}\right)$. Although the overall result of the test indicates that the productivity and salary levels of KIS are related to the size of the large metropolis of the country, the values observed in the MCMA are lower than expected according to size, while the value of the same indicators are above what was expected in the MMA. That is to say, in spite of the magnitude that the KIS reach in both indicators in the MCMA, they receive greater benefits in the MMA considering the size of both metropolis.

The benefits obtained by KIS located in large cities vary according to the type of knowledge they develop. Synthetic KIS is the category with the most important levels of productivity in the four larger metropolitan areas. For analytical and symbolic KIS, productivity is higher in metropolitan average than in the national average, although not substantially. Productivity of synthetic KIS located in MCMA and MMA is greater than the one obtained by the same services in any of the other two metropolitan areas. MCMA is the only metropolis where the analytical and symbolic KIS obtain productivities above the metropolitan average (Figure 3B).

During 2004 and 2014, differences in levels of productivity were reduced among economic sectors, with larger reductions in KIS and mining and extractive industries (Table A1 in Appendix A). The loss was associated with size, as productivity in the metropolitan areas was reduced 1.5 times compared to national average. If we break down the metropolitan group, the reduction can be attributed mostly to KIS located in MCMA, while those in MMA improved their productivity level. This last particularity is similar when distinguishing the type of knowledge developed by KIS. The outcome of the previous changes was the reduction in the productivity gap that exist between KIS and NKIS (Figure 3A). The significant reduction in the productivity levels of the KIS is contrary to what is expected by the literature; in the final section we reflect on this.

\subsection{Average Salaries}

The average salary received by personnel employed in KIS $(s=0.09)$ is above the national median (0.07). The average salaries of KIS are only below those received in mining and extraction activities (0.29), and electricity production (0.27). As in the previous indicator, city size has a positive effect on the salaries of economic activities in general. The KIS located in the four metropolises get 1.3 times higher than those activities in the national average. However, this indicator is much lower than mining and extractive activities and electricity at the metropolitan level (Table A2 in Appendix A).

Metropolitan group differences are remarkable, as average paid salaries is 1.6 times higher in MCMA (0.15) compared to the national average, while those KIS in the other three metropolitan areas show average paid salaries half this national figure. In fact, KIS are not necessarily activities enjoying paid salaries above some activities, such as mining, extractive industries, and electricity generation. Contrary to what is expected, KIS located in GMA (0.06), MMA (0.06), and PMA (0.05) receive salaries with values very close to those obtained by the NKIS $(0.04,0.10$, and 0.04 , respectively). Even in MMA the remunerations of KIS are lower than those obtained by the NKIS (Figure 4A).

Each category of KIS (analytical, synthetic, and symbolic) has different levels of average salaries across large national metropolises. Synthetic KIS located in large cities are those that receive the greatest benefits (0.15). However, this last characteristic only occurs in MCMA (0.20). The other three metropolis have values below the median. In contrast, the benefits offered by the larger metropolis seem not to operate in the analytical and symbolic KIS. In these two categories there are no substantive differences between their national ( 0.09 and 0.06 , respectively) and metropolitan averages ( 0.06 and 0.05 , respectively); except for analytical KIS in MMA (0.14). In general, average paid salaries to symbolic KIS employees are lower than the national median and very similar to the NKIS among the four metropolises (Figure 4B). 
(A)

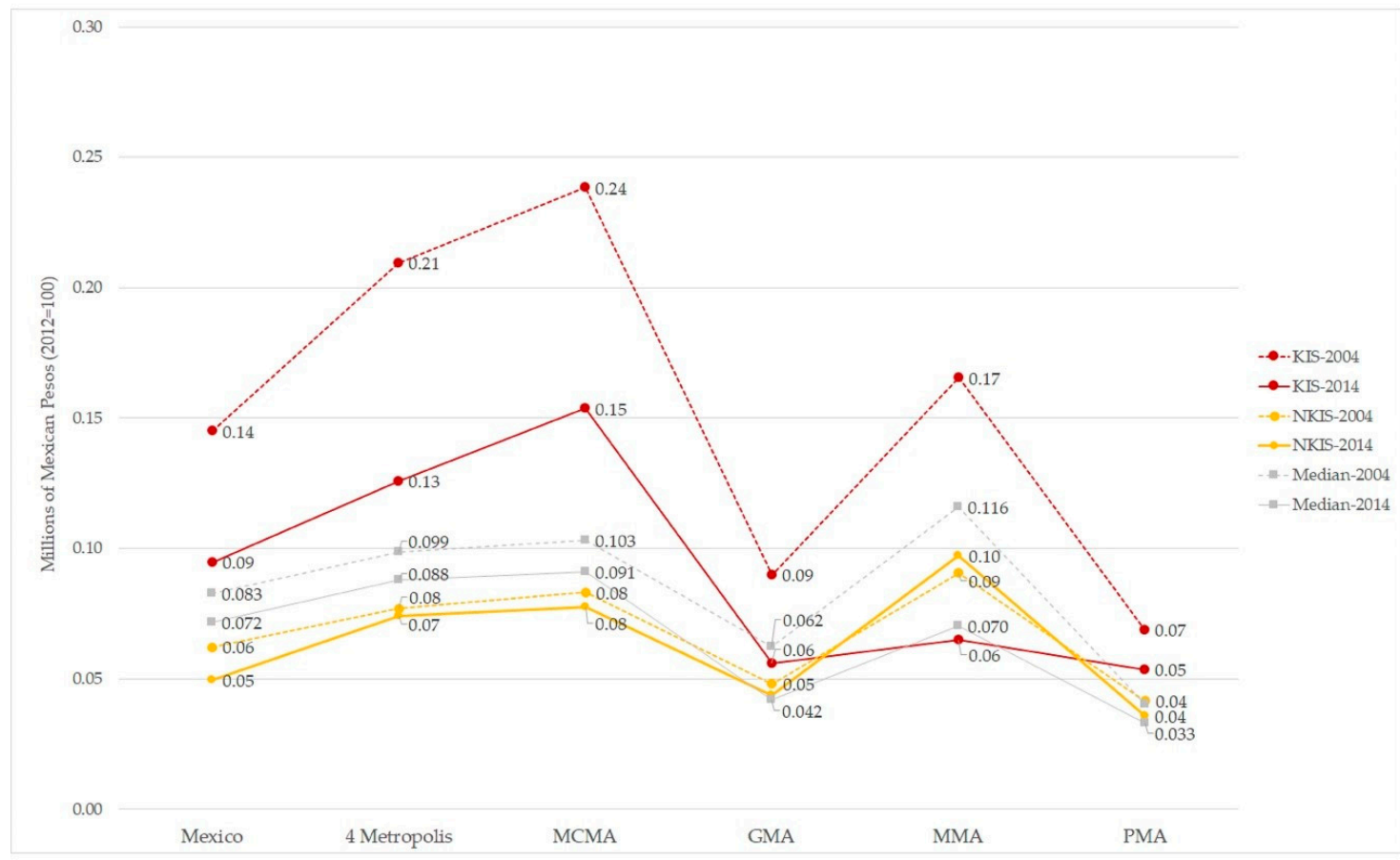

(B)

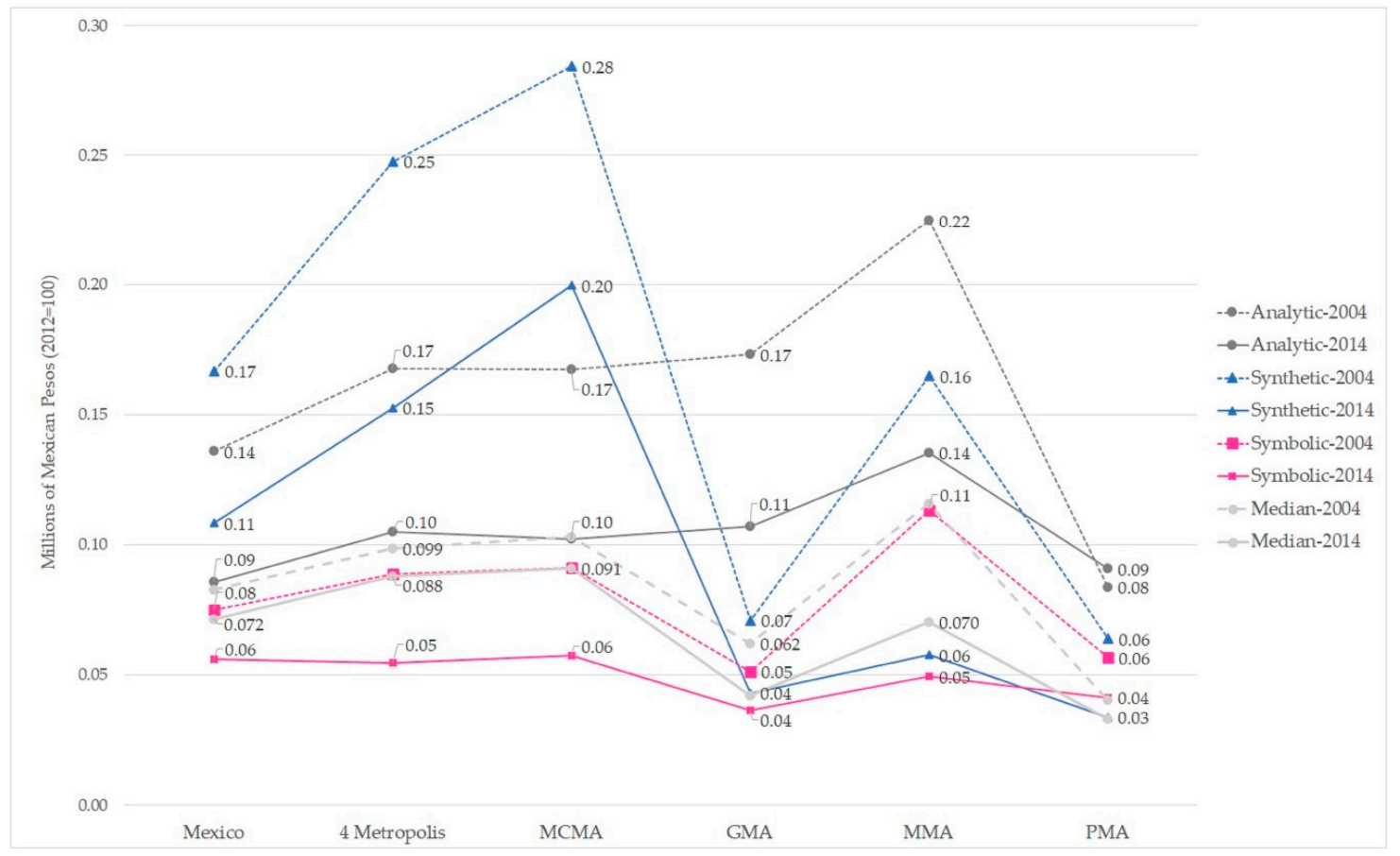

Figure 4. Mexico and four larger metropolitan areas: Salaries paid in services industries, 2004 and 2014.

(A) KIS and NKIS; (B) KIS by type of knowledge. Source: Table A2 in Appendix A. 
KIS experienced the most significant reduction in average salaries (-34.6\%) between 2004 and 2014. The reduction was more pronounced in two of our metropolitan areas: MMA (-60.8) and GMA $(-37.7 \%)$. Different categories of KIS presented important losses: analytical and symbolic KIS in MCMA, while synthetic and symbolic KIS in the other three metropolises. In contrast, the NKIS in the four larger metropolitan areas had reductions below their national average $(-20.2 \%)$ (Table A2 in Appendix A). The result of these changes was a remuneration gap reduction between intensive and non-intensive knowledge sectors in the larger national metropolis.

How to explain the higher productivities and salaries of electric production in the four metropolises? First, their corporate and administrative offices tend to locate their activity and logistics in the larger metropolitan areas analyzed; these are knowledge-intensive activities that have high productivities and receive high salaries, but data are not available through the industrial classification system. A second explanation is related to an accounting bias, since their financial activity is recorded in their headquarters, while their production is carried out somewhere else. These two observations, far from detracting from our analysis, underscore their importance within the urban economy.

The previous results indicate two "paradoxes" of KIS in the four larger metropolitan areas: (i) although KIS have high levels of productivity, their salary levels are lower than the national median, especially KIS synthetic and symbolic categories (only this is not the case in MCMA); and (ii) the gap in productivity and wages between KIS and NKIS has narrowed. These results have important implications in conceptual and economic policy terms on the idea of KIS as possible key activities in the growth of larger Mexican cities. These results are contrary to what is identified by the literature on this group of services in cities defined as central to the global economy. We present some reflections on the latter in the next section.

\section{Discussion and Concluding Remarks}

Our analysis shows that being a small group of activities in terms of its employment size, KIS are an important generator of value-added in the urban economy. In addition, KIS productivity levels just below mining, extractive industries, and electricity generation is probably explained by the fact that historically the Mexican economy was based in these industrial sectors for its development and growth in the second half of the 20th century.

Despite its small size, the role of KIS in Mexico is comparable to Canada [17] or England [47]. KIS location favors the larger metropolitan areas in the country ( $45 \%$ of employees and $74 \%$ of generated value-added of service activities). Its concentrated pattern responds to the importance of agglomeration economies and the strategic information and communication role they fulfill in the national and the global economy [17]. These factors explain their high productivity and the salaries paid to their employees, and show the positive impact of these metropolitan areas' agglomeration economies.

However, except for salaries paid, KIS productivity, generation of value-added, and personnel are not exactly associated with the size of the metropolitan areas. It seems that there is a gap between these metropolitan areas. MCMA and MMA concentrate those KIS sub-branches that achieve higher advantages in productivity and salaries paid. These differences imply that perhaps only those two metropolitan economies have the necessary urbanization economy attributes to attract innovations and technological skills to get involved in the global knowledge production dynamics. On the other hand, GMA and PMA, the second and fourth cities in the country in terms of size, present levels below the national average, which suggests that the KIS located in them do not have the adequate conditions for their development. Specific studies of these two cities are necessary to know the causes of their lag. Changes during 2004 and 2014 show important differences to what is to be expected from the revised literature. Contrary to what has been mentioned by various researchers $[28,81]$, who have identified a growing productive and wage gap between KIS and NKIS, as is the case in the US larger urban centers, an opposite trend occurs in Mexican larger metropolitan areas. Productivity and salaries paid in KIS were relatively reduced and a converging tendency seems to be at work with NKIS activities. This means that despite their high levels of qualification, KIS employees, especially those 
employed in synthetic and symbolic areas, have begun to have lower economic results and receive salaries that are closer to those received by those employed in NKIS. Our results show that a fall in relative advantages of location occurred in these metropolitan centers, which represents a "paradox" for the possible definition and promotion of KIS as "engines" of development of the large cities of Mexico. Previous results, however, should be further analyzed in the context of the evolution of the national urban system and more precisely in the already too long cycle of slow economic growth the Mexican economy has experienced.

This conclusion should be qualified when looking at the type of KIS activities. The conditions offered by large cities for the development of KIS vary depending on the type of knowledge developed by this type of service. Synthetic KIS show relatively higher productivity levels as well as higher average salaries paid, especially in MCMA and MMA. Symbolic KIS show the lower relative values in both measures in the four metropolitan areas, while analytical KIS show relatively higher salaries paid, probably due to the attention the Mexican government gave to research and higher education and the creation of scientific research centers during the period. This outcome indicates that in our "developing country" context, synthetic and analytic KIS activities are better positioned to take advantage of a spatial innovative milieu compared to symbolic knowledge intensive services.

Finally, yet importantly, our results qualify other proposals assuming linear relations between economic performance based on location and size of cities. The evidence presented suggests that it is not only size that determines the attraction of qualified jobs and innovative activities, but connectivity and specific attributes of the urban milieu that allow exchange of knowledge as well as efficiency in economic activities according to the type and intensity of knowledge required and developed by these services. The exploratory character of this exercise presents, to our understanding, important evidence of the role KIS could play in the peripheral urban centers of the world economy. We expect other cities in the Global South, particularly in Latin América, could confirm our results. But it is still necessary to focus in other cities within the national urban system (by size, distance from the main metropolitan areas, and from the northern border, etc.) to weight their potential to develop high-tech clusters and offer the innovative milieu to attract KIS. As Shearmur [82] pointed out, it is necessary to identify spatial and technological factors determining results. In some cases, local conditions in small towns near large urban centers offer opportunities for location of some phases in the development of innovations. We would expect physical and/or virtual proximity might complement or substitute exchange of knowledge the spatial urban milieu provides.

Author Contributions: For research articles with several authors, a short paragraph specifying their individual contributions must be provided. Conceptualization, B.G. and L.E.S.; methodology, B.G.; validation, B.G. and L.E.S.; formal analysis, B.G. and L.E.S.; data curation, L.E.S.; writing-original draft preparation, B.G. and L.E.S.; writing-review and editing, B.G. and L.E.S. All authors have read and agreed to the published version of the manuscript.

Funding: This research received no external funding

Conflicts of Interest: The authors declare no conflict of interest. 


\section{Appendix A}

Table A1. Mexico and metropolitan areas: Productivity by economic sectors, KIS and NKIS, 2004 and 2014 (millions of Mexican Pesos, 2012 = 100).

\begin{tabular}{|c|c|c|c|c|c|c|c|c|c|c|c|c|c|c|c|c|c|c|}
\hline & \multicolumn{12}{|c|}{ Absolut } & \multicolumn{6}{|c|}{ Growth } \\
\hline & \multicolumn{2}{|c|}{ A } & \multicolumn{2}{|c|}{ B } & \multicolumn{2}{|c|}{ C } & \multicolumn{2}{|c|}{ D } & \multicolumn{2}{|c|}{$E$} & \multicolumn{2}{|c|}{ F } & \multirow{2}{*}{ A } & \multirow{2}{*}{ B } & \multirow{2}{*}{$\mathrm{C}$} & \multirow{2}{*}{ D } & \multirow{2}{*}{$\mathrm{E}$} & \multirow{2}{*}{$\mathbf{F}$} \\
\hline & 2004 & 2014 & 2004 & 2014 & 2004 & 2014 & 2004 & 2014 & 2004 & 2014 & 2004 & 2014 & & & & & & \\
\hline Total & 0.31 & 0.27 & 0.35 & 0.30 & 0.38 & 0.33 & 0.24 & 0.19 & 0.36 & 0.33 & 0.28 & 0.24 & -12.9 & -12.9 & -13.3 & -21.6 & -7.5 & -12.0 \\
\hline Agriculture $^{\mathrm{a}}$ & 0.06 & 0.07 & 0.03 & 0.01 & 0.03 & 0.01 & 0.00 & 0.00 & 0.00 & 0.00 & 0.00 & 0.00 & 6.5 & -72.5 & -53.1 & 0.0 & 0.0 & 0.0 \\
\hline Mining and extraction & 5.85 & 6.08 & -0.08 & -0.52 & -0.37 & -0.86 & 0.36 & -0.05 & 0.41 & 0.61 & 0.14 & 0.13 & 4.0 & 588.3 & 131.5 & -112.5 & 47.7 & -10.4 \\
\hline Electricity & 1.34 & 1.13 & 1.96 & 1.86 & 1.84 & 1.90 & 3.05 & 0.00 & 1.54 & 1.15 & 0.00 & 0.00 & -15.5 & -5.3 & 3.1 & -100.0 & -25.1 & 0.0 \\
\hline Construction & 0.14 & 0.18 & 0.15 & 0.21 & 0.14 & 0.23 & 0.11 & 0.17 & 0.23 & 0.20 & 0.16 & 0.15 & 32.8 & 33.8 & 61.3 & 51.4 & -13.4 & -8.7 \\
\hline Manufacture & 0.34 & 0.33 & 0.35 & 0.35 & 0.31 & 0.29 & 0.30 & 0.31 & 0.45 & 0.41 & 0.51 & 0.50 & -1.9 & -2.3 & -4.4 & 1.4 & -9.2 & -3.4 \\
\hline Trade and transportation & 0.18 & 0.15 & 0.23 & 0.18 & 0.24 & 0.18 & 0.22 & 0.16 & 0.26 & 0.19 & 0.16 & 0.15 & -17.4 & -23.1 & -22.7 & -26.4 & -25.7 & -7.8 \\
\hline Services $^{b}$ & 0.29 & 0.21 & 0.44 & 0.32 & 0.53 & 0.37 & 0.14 & 0.11 & 0.32 & 0.36 & 0.13 & 0.09 & -28.2 & -26.6 & -31.3 & -24.6 & 15.3 & -33.0 \\
\hline KIS $^{c}$ & 0.66 & 0.42 & 1.05 & 0.68 & 1.27 & 0.78 & 0.19 & 0.18 & 0.54 & 0.76 & 0.28 & 0.11 & -36.8 & -35.3 & -38.5 & -9.1 & 41.2 & -59.2 \\
\hline Analytical & 0.22 & 0.16 & 0.29 & 0.18 & 0.28 & 0.19 & 0.28 & 0.17 & 0.42 & 0.20 & 0.18 & 0.17 & -30.3 & -37.4 & -33.7 & -38.8 & -53.2 & -8.2 \\
\hline Synthetic & 0.84 & 0.56 & 1.33 & 0.94 & 1.59 & 1.12 & 0.17 & 0.20 & 0.59 & 0.91 & 0.38 & 0.09 & -33.2 & -29.3 & -29.8 & 16.1 & 53.1 & -75.3 \\
\hline Symbolic & 0.31 & 0.16 & 0.41 & 0.18 & 0.44 & 0.20 & 0.16 & 0.08 & 0.42 & 0.14 & 0.16 & 0.06 & -50.6 & -55.6 & -55.2 & -50.4 & -66.9 & -61.8 \\
\hline NKIS $^{d}$ & 0.18 & 0.15 & 0.21 & 0.22 & 0.23 & 0.24 & 0.13 & 0.09 & 0.24 & 0.27 & 0.09 & 0.08 & -12.9 & 4.6 & 5.8 & -31.3 & 9.7 & -9.6 \\
\hline \multicolumn{19}{|l|}{ Descriptive Statistics } \\
\hline Average & 1.09 & 1.07 & 0.49 & 0.37 & 0.46 & 0.35 & 0.55 & 0.11 & 0.46 & 0.45 & 0.17 & 0.14 & -2.6 & -24.0 & -24.4 & -80.4 & -2.2 & -17.0 \\
\hline Median & 0.26 & 0.26 & 0.22 & 0.21 & 0.23 & 0.24 & 0.21 & 0.13 & 0.34 & 0.34 & 0.15 & 0.12 & -1.4 & -3.4 & 2.0 & -39.3 & 0.4 & -20.3 \\
\hline Maximum & 5.85 & 6.08 & 1.96 & 1.86 & 1.84 & 1.90 & 3.05 & 0.31 & 1.54 & 1.15 & 0.51 & 0.50 & 4.0 & -5.3 & 3.1 & -89.9 & -25.1 & -3.4 \\
\hline 3rd Quartile & 0.83 & 0.60 & 0.53 & 0.43 & 0.55 & 0.41 & 0.32 & 0.17 & 0.47 & 0.65 & 0.19 & 0.15 & -28.2 & -18.7 & -24.2 & -47.1 & 36.8 & -23.3 \\
\hline 2nd Quartile & 0.26 & 0.26 & 0.22 & 0.21 & 0.23 & 0.24 & 0.21 & 0.13 & 0.34 & 0.34 & 0.15 & 0.12 & -1.4 & -3.4 & 2.0 & -39.3 & 0.4 & -20.3 \\
\hline 1st Quartile & 0.17 & 0.15 & 0.12 & 0.14 & 0.12 & 0.14 & 0.13 & 0.00 & 0.24 & 0.20 & 0.07 & 0.06 & -8.2 & 10.5 & 22.1 & -100.0 & -17.2 & -8.3 \\
\hline Minimum & 0.06 & 0.07 & -0.08 & -0.52 & -0.37 & -0.86 & 0.00 & -0.05 & 0.00 & 0.00 & 0.00 & 0.00 & 6.5 & 588.3 & 131.5 & 0.0 & 0.0 & 0.0 \\
\hline Standard deviation & 1.97 & 2.06 & 0.69 & 0.69 & 0.72 & 0.78 & 1.02 & 0.12 & 0.47 & 0.37 & 0.17 & 0.16 & 4.5 & 0.6 & 7.1 & -88.4 & -19.7 & -6.8 \\
\hline Coef. Var. & 0.00 & 0.00 & 0.00 & 0.00 & 0.00 & 0.00 & 0.00 & 0.00 & 0.00 & 0.00 & 0.00 & 0.00 & 7.3 & 32.4 & 41.7 & -40.7 & -17.8 & 12.4 \\
\hline
\end{tabular}

Note: $\mathrm{A}=$ Mexico; $\mathrm{B}=4$ Metropolis; $\mathrm{C}=$ Mexico City; $\mathrm{D}=$ Guadalajara; $\mathrm{E}=$ Monterrey; $\mathrm{F}=$ Puebla. ${ }^{\text {a }}$ The economic sectors are defined in NAICS with two digits of disaggregation as:

(11) Agriculture; (21) Mining and extraction; (22) Electricity; (23) Construction; (31-32) Manufacture; and, (43, 46,48 and 49$)$ Trade and transportation. ${ }^{b}$ Services is the sum of KIS and NKIS. ${ }^{c}$ KIS and their categories (analytical, synthetic, and symbolic) from Table $1 .{ }^{\mathrm{d}}$ NKIS is formed by the sub-branches (five digits) that are not defined as KIS of the following sectors: (51) Information in mass media, (52) Financial an insurance services, (53) Real estate, (55) Corporate, (56) Business support services and waste management, (61) Educational services, (62) Health and social assistance services, (71) Cultural, sport entertainment and recreational services, (72) Temporary accommodation and food services, and (81) Other services except government activities. Source: [76,77]. 
Table A2. Mexico and metropolitan areas: Salaries paid by economic sectors, KIS and NKIS, 2004 y 2014 (millions of Mexican Pesos, 2012 = 100).

\begin{tabular}{|c|c|c|c|c|c|c|c|c|c|c|c|c|c|c|c|c|c|c|}
\hline & \multicolumn{12}{|c|}{ Absolute } & \multicolumn{6}{|c|}{ Growth } \\
\hline & \multicolumn{2}{|c|}{ A } & \multicolumn{2}{|c|}{ B } & \multicolumn{2}{|c|}{ C } & \multicolumn{2}{|c|}{ D } & \multicolumn{2}{|c|}{$\mathrm{E}$} & \multicolumn{2}{|c|}{ F } & \multirow{2}{*}{ A } & \multirow{2}{*}{ B } & \multirow{2}{*}{ C } & \multirow{2}{*}{ D } & \multirow{2}{*}{$\mathrm{E}$} & \multirow{2}{*}{$\mathbf{F}$} \\
\hline & 2004 & 2014 & 2004 & 2014 & 2004 & 2014 & 2004 & 2014 & 2004 & 2014 & 2004 & 2014 & & & & & & \\
\hline Total & 0.08 & 0.06 & 0.10 & 0.08 & 0.11 & 0.09 & 0.07 & 0.06 & 0.11 & 0.09 & 0.07 & 0.06 & -18.3 & -17.5 & -17.2 & -19.3 & -19.3 & -14.6 \\
\hline Mining and extraction & 0.22 & 0.29 & 0.32 & 0.72 & 0.43 & 1.04 & 0.07 & 0.02 & 0.17 & 0.08 & 0.03 & 0.03 & 34.4 & 122.9 & 141.6 & -76.3 & -56.3 & -16.6 \\
\hline Electricity & 0.22 & 0.27 & 0.25 & 0.42 & 0.23 & 0.44 & 0.33 & 0.00 & 0.25 & 0.20 & 0.00 & 0.00 & 23.9 & 67.3 & 87.3 & -100.0 & -21.9 & 0.0 \\
\hline Construction & 0.05 & 0.05 & 0.05 & 0.05 & 0.06 & 0.05 & 0.04 & 0.05 & 0.06 & 0.05 & 0.05 & 0.06 & 11.7 & -4.1 & -15.7 & 28.2 & -9.6 & 25.7 \\
\hline Manufacture & 0.10 & 0.09 & 0.12 & 0.10 & 0.12 & 0.10 & 0.09 & 0.08 & 0.14 & 0.11 & 0.11 & 0.10 & -12.9 & -15.6 & -15.3 & -12.6 & -20.1 & -8.8 \\
\hline Trade and transportation & 0.05 & 0.04 & 0.07 & 0.05 & 0.07 & 0.05 & 0.05 & 0.04 & 0.07 & 0.06 & 0.04 & 0.03 & -23.3 & -31.3 & -35.1 & -23.0 & -22.4 & -22.2 \\
\hline Services ${ }^{b}$ & 0.08 & 0.06 & 0.11 & 0.09 & 0.13 & 0.09 & 0.06 & 0.05 & 0.11 & 0.09 & 0.05 & 0.04 & -27.7 & -24.1 & -26.1 & -18.2 & -16.9 & -17.2 \\
\hline $\mathrm{KIS}^{\mathrm{c}}$ & 0.14 & 0.09 & 0.21 & 0.13 & 0.24 & 0.15 & 0.09 & 0.06 & 0.17 & 0.06 & 0.07 & 0.05 & -34.6 & -39.9 & -35.5 & -37.7 & -60.8 & -21.9 \\
\hline Analytical & 0.14 & 0.09 & 0.17 & 0.10 & 0.17 & 0.10 & 0.17 & 0.11 & 0.22 & 0.14 & 0.08 & 0.09 & -36.8 & -37.4 & -39.0 & -38.2 & -39.8 & 8.4 \\
\hline Synthetic & 0.17 & 0.11 & 0.25 & 0.15 & 0.28 & 0.20 & 0.07 & 0.04 & 0.16 & 0.06 & 0.06 & 0.03 & -35.1 & -38.4 & -29.8 & -39.4 & -65.0 & -47.1 \\
\hline Symbolic & 0.08 & 0.06 & 0.09 & 0.05 & 0.09 & 0.06 & 0.05 & 0.04 & 0.11 & 0.05 & 0.06 & 0.04 & -25.4 & -38.5 & -37.1 & -28.8 & -56.5 & -27.2 \\
\hline NKIS $^{d}$ & 0.06 & 0.05 & 0.08 & 0.07 & 0.08 & 0.08 & 0.05 & 0.04 & 0.09 & 0.10 & 0.04 & 0.04 & -20.2 & -3.6 & -6.8 & -9.3 & 7.2 & -14.3 \\
\hline \multicolumn{19}{|l|}{ Descriptive Statistics } \\
\hline Median & 0.08 & 0.07 & 0.10 & 0.09 & 0.10 & 0.09 & 0.06 & 0.04 & 0.12 & 0.07 & 0.04 & 0.03 & -13.7 & -10.9 & -11.9 & -32.4 & -39.2 & -18.1 \\
\hline Maximum & 0.22 & 0.29 & 0.32 & 0.72 & 0.43 & 1.04 & 0.33 & 0.08 & 0.25 & 0.20 & 0.11 & 0.10 & 32.0 & 122.9 & 141.6 & -74.8 & -21.9 & -8.8 \\
\hline 3rd Quartile & 0.16 & 0.14 & 0.22 & 0.20 & 0.23 & 0.22 & 0.09 & 0.05 & 0.17 & 0.10 & 0.05 & 0.05 & -14.4 & -9.1 & -4.2 & -39.7 & -39.8 & 6.2 \\
\hline 2nd Quartile & 0.08 & 0.07 & 0.10 & 0.09 & 0.10 & 0.09 & 0.06 & 0.04 & 0.12 & 0.07 & 0.04 & 0.03 & -13.7 & -10.9 & -11.9 & -32.4 & -39.2 & -18.1 \\
\hline 1st Quartile & 0.05 & 0.05 & 0.06 & 0.05 & 0.07 & 0.05 & 0.05 & 0.01 & 0.07 & 0.05 & 0.02 & 0.02 & -4.7 & -19.9 & -26.6 & -72.6 & -19.7 & -16.1 \\
\hline Minimum & 0.02 & 0.01 & 0.01 & 0.00 & 0.01 & 0.00 & 0.00 & 0.00 & 0.00 & 0.00 & 0.00 & 0.00 & -4.9 & -79.3 & -63.8 & 0.0 & 0.0 & 0.0 \\
\hline Standard deviation & 0.08 & 0.11 & 0.11 & 0.25 & 0.14 & 0.35 & 0.10 & 0.03 & 0.08 & 0.06 & 0.04 & 0.03 & 36.5 & 124.7 & 154.2 & -70.9 & -27.9 & -8.4 \\
\hline Coef. Var. & 0.00 & 0.00 & 0.00 & 0.00 & 0.00 & 0.00 & 0.00 & 0.00 & 0.00 & 0.00 & 0.00 & 0.00 & 29.8 & 61.6 & 65.6 & -28.2 & 4.8 & 1.4 \\
\hline
\end{tabular}

Note: $\mathrm{A}=$ Mexico; $\mathrm{B}=4$ Metropolis; $\mathrm{C}=$ Mexico City; $\mathrm{D}=$ Guadalajara; $\mathrm{E}=$ Monterrey; $\mathrm{F}=$ Puebla. ${ }^{\text {a }}$ The economic sectors are defined in NAICS with two digits of disaggregation as: (11) Agriculture; (21) Mining and extraction; (22) Electricity; (23) Construction; (31,32) Manufacture; and, (43, 46,48 and 49$)$ Trade and transportation. ${ }^{b}$ Services is the sum of KIS and NKIS. ${ }^{~}$ KIS and their categories (analytical, synthetic and symbolic) from Table $1 .{ }^{\mathrm{d}}$ NKIS is formed by the sub-branches (five digits) that are not defined as KIS of the following sectors:

(51) Information in mass media, (52) Financial an insurance services, (53) Real estate, (55) Corporate, (56) Business support services and waste management, (61) Educational services,

(62) Health and social assistance services, (71) Cultural, sport entertainment and recreational services, (72) Temporary accommodation and food services, and (81) Other services except government activities. Source: $[76,77]$. 


\section{References}

1. Shearmur, R.; Doloreux, D. KIBS as both innovators and knowledge intermediaries in the innovation process: Intermediation as a contingent role. Pap. Reg. Sci. 2018, 98, 191-209. [CrossRef]

2. Glückler, J.; Hammer, I. A new service typology: Geographical diversity and dynamics of the German service economy. In Service Industries and Regions: Growth, Location and Regional Effects; Cuadrado-Roura, J.R., Ed.; Springer: New York, NY, USA, 2014; pp. 339-364.

3. Gallouj, F.; Savona, M. Innovation in services: A review of the debate and a research agenda. J. Evol. Econ. 2009, 19, 149-172. [CrossRef]

4. Mudambi, R. Location, control and innovation in knowledge-intensive industries. J. Econ. Geogr. 2008, 8, 699-725. [CrossRef]

5. Graizbord, B.; Santiago, L.E. Ciudades y conocimiento. Clase creativa y servicios de alto contenido de conocimiento en las zonas metropolitanas de México. In Desarrollo Urbano y Metropolitano en México; Sobrino, J., Ugalde, V., Eds.; El Colegio de México: Mexico City, Mexico, 2019; pp. 205-251.

6. Pina, K.; Tether, B.S. Towards understanding variety in knowledge intensive business services by distinguishing their knowledge base. Res. Policy 2016, 45, 401-413. [CrossRef]

7. Gallego, M.; Maroto, S. The specialization in knowledge-intensive business services (KIBS) across Europe: Permanent co-localization to debate. Reg. Stud. 2015, 49, 644-664. [CrossRef]

8. Shearmur, R.; Doloreux, D. Central places or networks? Paradigms, metaphors, and spatial configurations of innovation-related service use. Environ. Plan. A 2015, 47, 1521-1539. [CrossRef]

9. Angoa, I.; Pérez-Mendoza, S.; Polèse, M. Los tres Méxicos: Análisis de la distribución del empleo en la industria y los servicios superiores, por tamaño urbano y región. EURE 2009, 35, 121-143. [CrossRef]

10. Camagni, R. Regional clusters, regional competencies and regional competition. In Proceedings of the International Conference on Cluster Management in Structural Policy-International Experiences and Consequences for Northrhine-Westfalia, Duisburg, Germany, 5 December 2003; Available online: http://citeseerx.ist.psu.edu/viewdoc/download?doi=10.1.1.197.4247\&rep=rep1\&type=pdf (accessed on 10 October 2020).

11. Glaeser, E.; Gottlieb, J. The Wealth of Cities: Agglomeration Economies and Spatial Equilibrium in the US; Technical Report No. 14806; National Bureau of Economic Research: Cambridge, MA, USA, 2020.

12. Echeverri-Carroll, E.; Ayala, S. Urban wages: Does city size matter? Urban Stud. 2011, 48, 253-271. [CrossRef]

13. Piore, M.; Sabel, C. The Second Industrial Divide: Possibilities for Prosperity; Basic Books: New York, NY, USA, 1984.

14. Fisher, A. Progreso Económico y Seguridad Social; Fondo de Cultura Económica: Mexico City, Mexico, 1949.

15. Clark, C. Las Condiciones del Progreso Económico; Alianza: Madrid, Spain, 1980.

16. Piketty, T. El capital en el Siglo XXI; Fondo de Cultura Económica: Mexico City, Mexico, 2014.

17. Shearmur, R.; Doloreux, D. Urban hierarchy or local buzz? High-order producer services and (or) knowledge-intensive business services innovation. Prof. Geogr. 2008, 60, 333-355. [CrossRef]

18. Zhang, C. Agglomeration of knowledge intensive business services and urban productivity. Pap. Reg. Sci. 2016, 95, 801-818. [CrossRef]

19. Zhang, C. Agglomeration economies and performance in knowledge-intensive business services. Singap. Econ. Rev. 2020, 65, 457-469. [CrossRef]

20. Sobrino, J.L. Entre mitos y realidades: Ciudades mexicanas que concentran clase creativa. Estudios Demográficos y Urbanos 2016, 31, 501-522. [CrossRef]

21. Vendrell-Herrero, F.; Darko, C.K.; Ghauri, P. Knowledge management competences, exporting and productivity: Uncovering African paradoxes. J. Knowl. Manag. 2019, 24, 81-104. [CrossRef]

22. Santos, J. Knowledge-intensive business services and innovation performance in Brazil. Innov. Manag. Rev. 2019, 17, 58-74. [CrossRef]

23. Hall, P. The world's urban systems: A European perspective. Glob. Urban Dev. 2005, 1, 1-12.

24. Howells, J.; Ramlogan, R.; Cheng, S. Innovation and university collaboration: Paradox and complexity within the knowledge economy. Camb. J. Econ. 2012, 36, 703-721. [CrossRef]

25. Audretsch, D.; Keilbach, M. Resolving the knowledge paradox: Knowledge-spillover entrepreneurship and economic growth. Res. Policy 2008, 37, 1697-1705. [CrossRef]

26. Florida, R. Cities and the Creative Class; Routledge: Abingdon, UK, 2005. 
27. Florida, R.; Mellander, C. The geography of inequality: Difference and determinants of wage and income inequality across US metros. Reg. Stud. 2016, 50, 79-92. [CrossRef]

28. Autor, D.; Katz, L.; Salomons, M. The Polarization of the US labor market. Am. Econ. Rev. 2006, 96, 189-194. [CrossRef]

29. Maroto, A.; Rubalcaba, L. Services productivity revisited. Serv. Ind. J. 2008, 28, 337-353. [CrossRef]

30. De Fuentes, C.; Dutrenit, G.; Santiago, F.; Gras, N. Determinants of innovation and productivity in the service sector in Mexico. Emerg. Mark. Financ. Tr. 2015, 51, 578-592. [CrossRef]

31. Álvarez, R.; Bravo-Ortega, C.; Zahler, A. Innovation and productivity in services: Evidence from Chile. Emerg. Mark. Financ. Tr. 2015, 51, 593-611. [CrossRef]

32. Masso, J.; Vahter, P. The Link between Innovation and Productivity in Estonia's Service Sectors; Technical Report No. 1012; William Davidson Institute: Michigan, MI, USA, 2012.

33. Hipp, C.; Grupp, H. Innovation in the service sector: The demand for service-specific innovation measurement concepts and typologies. Res. Policy 2005, 34, 517-535. [CrossRef]

34. Manning, A. We can work it out: The impact of technological change on the demand for low-skill workers. Scott. J. Political Econ. 2004, 51, 581-608. [CrossRef]

35. Warf, B. Introduction: Geography, technology, society. In Handbook on Geographies of Technology; Warf, B., Ed.; Edward Elgar Publishing: Northampton, MA, USA, 2017; pp. 1-13.

36. Dicken, P. Global Shift: Mapping the Changing Contours of the World Economy, 7th ed.; SAGE Publications: London, UK, 2015.

37. Bryson, J. The second global shift: The offshoring or global sourcing of corporate services and the rise of distanciated emotional labour. Geogr. Ann. B Hum. Geogr. 2007, 89, 31-43. [CrossRef]

38. Autor, D.; Dorn, D. The growth of low-skill service jobs and the polarization of the US labor market. Am. Econ. Rev. 2013, 103, 1553-1597. [CrossRef]

39. Moretti, E. The New Geography of Jobs; Mariner Books: New York, NY, USA, 2013.

40. Castells, M. The Rise of the Network Society; Wiley-Blackwell: Oxford, UK, 1996.

41. Daniels, P.; Bryson, J. Manufacturing services and servicing manufacturing: Knowledge-based cities and changing forms of production. Urban Stud. 2002, 39, 977-991. [CrossRef]

42. Hall, P. Looking backward, looking forward: The city region of the mid-21st century. Reg. Stud. 2009, 6, 803-817. [CrossRef]

43. Asheim, B. Innovating: Creativity, innovation and the role of cities in the globalizing knowledge economy. In Building Prosperous Knowledge Cities: Policies, Plans and Metrics; Yigitcanlar, T., Metaxiotis, K., Carrillo, F., Eds.; Edward Elgar Publishing: Northampton, MA, USA, 2012; pp. 3-23.

44. Moomaw, R. Productivity and city size: A Critique of the evidence. Q. J. Econ. 1981, 4, 675-688. [CrossRef]

45. Glaeser, E.; Maré, D. Cities and skills. J. Labour Econ. 2001, 19, 316-342. [CrossRef]

46. Bryson, J.; Rusten, G. Spatial Divisions of expertise: Knowledge intensive business service firms and regional development in Norway. Serv. Ind. J. 2005, 25, 959-977. [CrossRef]

47. Wood, P. Urban development and knowledge-intensive business services: Too many unanswered questions? Growth Chang. 2006, 37, 335-361. [CrossRef]

48. Andersson, M.; Lööf, H. Agglomeration and productivity: Evidence from firms-level data. Ann. Reg. Sci. 2011, 46, 601-620. [CrossRef]

49. Chen, J.; Zhou, Q. City size and urban labor productivity in China: New evidence from spatial city-level panel data analysis. Econ. Syst. Res. 2017, 41, 165-178. [CrossRef]

50. Ahrend, R.; Lembcke, A.; Schumann, A. The role of urban agglomerations for economic productivity growth. Int. Product. Monitor 2017, 32, 161-179.

51. De la Roca, J.; Puga, D. Learning by working in big cities. Rev. Econ. Stud. 2017, 84, 106-142. [CrossRef]

52. Combes, P.; Duranton, G.; Gobillon, L. Spatial wage disparities: Sorting matters! J. Urban Econ. 2007, 63, 723-742. [CrossRef]

53. Abel, J.; Dey, I.; Gabe, T. Productivity and the density of human capital. J. Reg. Sci. 2012, 52, 562-586. [CrossRef]

54. Jones, C.; Romer, P. The new Kaldor facts: Ideas, institutions, population and human capital. Am. Econ. J. Macroecon. 2010, 2, 224-245. [CrossRef]

55. Storper, M.; Venables, A. Buzz: Face-to-face contact and the urban economy. J. Econ. Geogr. 2004, 4, 351-370. [CrossRef] 
56. Duranton, G.; Puga, D. Micro-foundations of urban agglomeration economies. In Handbook of Regional and Urban Economics; Henderson, J., Thisse, J., Eds.; Elsevier: London, UK, 2004; pp. 2063-2117.

57. Puga, D. The Magnitude and causes of agglomeration economies. J. Reg. Sci. 2010, 50, 203-219. [CrossRef]

58. Andersson, M.; Klaesson, J.; Larsson, J. The sources of the urban wage premium by worker skills: Spatial sorting or agglomeration economies? Pap. Reg. Sci. 2014, 93, 727-747. [CrossRef]

59. Westeren, K. Innovation: From Schumpeter to the knowledge economy. In Foundation of the Knowledge Economy: Innovation, Learning and Clusters; Westeren, K., Ed.; Edward Elgar Publishing: Northampton, MA, USA, 2012; pp. 57-74.

60. Sveikauskas, L. The productivity of cities. Q. J. Econ. 1975, 89, 393-413. [CrossRef]

61. Lucas, R. On the mechanics of economic development. J. Monet. Econ. 1988, 22, 3-42. [CrossRef]

62. Glaeser, E. Triumph of the City: How Our Greatest Invention Makes Us Richer, Smarter, Greener, Healthier and Happier; Penguin Books: London, UK, 2011.

63. Gertler, M. Tacit knowledge and the economic geography of context, or the undefinable tacitness of being (there). J. Econ. Geogr. 2003, 3, 75-99. [CrossRef]

64. Storper, M.; Kemeny, T.; Makarem, N.; Osman, T. The Rise and Fall of Urban Economies: Lessons from San Francisco and Los Angeles; Stanford University Press: Palo Alto, CA, USA, 2015.

65. Van Winden, W.; Carvalho, L. Urbanize or perish? Assessing the urbanization of knowledge locations in Europe. J. Urban Technol. 2016, 23, 53-70. [CrossRef]

66. Consejo Nacional de Población. Delimitación de las Zonas Metropolitanas de México. 2015. Available online: https://www.gob.mx/conapo/documentos/delimitacion-de-las-zonas-metropolitanas-de-mexico2015 (accessed on 10 October 2020).

67. Graizbord, B.; Rowland, A.; Aguilar, A.G. Mexico City as a peripheral global player: The two side of the coin. Ann. Reg. Sci. 2003, 37, 501-518. [CrossRef]

68. United Nation. The World's Cities in 2018. Available online: https://www.un.org/en/events/citiesday/assets/ pdf/the_worlds_cities_in_2018_data_booklet.pdf (accessed on 10 October 2020).

69. Romo, A.; Villalobos, A.; Toriz, A. Clusters and high technology industries in Mexico: A theoretical review. Organ. Stud. 2015, 2, 32-44.

70. Santiago, L.E. The industries of the future in Mexico: Local and non-local effects in the localization of "knowledge-intensive services". Growth Chang. 2020, 51, 584-606. [CrossRef]

71. Ichikawa, I.; Yamato, N.; Dustan, P. Competitiveness of global cities from the perspective of the global power city index. Procedia Eng. 2017, 198, 736-742. [CrossRef]

72. Berrone, P.; Ricart, J. IESE Cities in Motion Index 2018; IESE Business School, University of Navarra: Pamplona, Spain, 2018.

73. Institute for Urban Strategies. Global Power City Index. 2019. Available online: http://www.mori-mfoundation.or.jp/pdf/GPCI2019_summary.pdf (accessed on 10 October 2020).

74. Economist Intelligence Unit. Hot Spots 2025. Benchmarking the Future Competitiveness of Cities. 2013. Available online: https://www.citigroup.com/citi/citiforcities/pdfs/hotspots2025.pdf (accessed on 10 October 2020).

75. Panreiter, C. Global cities in global commodity chains: Exploring the role of Mexico City in the geography of global economic governance. Glob. Netw. 2010, 10, 35-53. [CrossRef]

76. National Institute of Statistics, Geography and Informatics (INEGI). Economic Censuses. 2004. Available online: http://en.www.inegi.org.mx/programas/ce/2004/ (accessed on 10 October 2020).

77. National Institute of Statistics. Geography and Informatics (INEGI). 2014. Available online: http://en.www. inegi.org.mx/programas/ce/2014/ (accessed on 10 October 2020).

78. Santiago, L.E. Ciudades, conocimiento e innovación: Estructura y Distribución Espacial de los Servicios Intensivos en Conocimiento Entre las Zonas Metropolitanas de México. Ph.D. Thesis, El Colegio de México, Mexico City, Mexico, 2016.

79. OECD (Organisation for Economic Cooperation and Development). Measuring Productivity OECD Manual: Measurement of Aggregate and Industry-Level Productivity Growth. 2001. Available online: http://www.oecd.org/sdd/productivity-stats/2352458.pdf (accessed on 10 October 2020).

80. Haltiwanger, J.; Lane, J.; Spletzer, J. Wages, productivity, and the dynamic interaction of businesses and workers. J. Labour Econ. 2007, 14, 575-602. [CrossRef] 
81. Lindley, J.; Machine, S. Spatial changes in labour market inequality. J. Urban Econ. 2014, 79, 121-138. [CrossRef]

82. Shearmur, R. Are cities the font of innovation? A critical review of the literature on cities and innovation. Cities 2012, 29, 9-18. [CrossRef]

Publisher's Note: MDPI stays neutral with regard to jurisdictional claims in published maps and institutional affiliations.

(C) 2020 by the authors. Licensee MDPI, Basel, Switzerland. This article is an open access article distributed under the terms and conditions of the Creative Commons Attribution (CC BY) license (http://creativecommons.org/licenses/by/4.0/). 